\title{
An epidermoid cyst presenting as testicular torsion in a patient with tri-orchidism
}

Deirdre Mary Fanning, Ted Mc Dermott

Department of Urology, St. James's Hospital, Dublin, Ireland

Correspondence to Deirdre Mary Fanning, fanningdee@yahoo.co.uk

\section{DESCRIPTION}

A 38-year-old male presented to the emergency department with acute onset of scrotal pain. The pain was excruciating. A prior scrotal ultrasound was consistent with polyorchidism (figures 1 and 2). Clinical examination revealed a markedly distressed tearful man. Scrotal inspection showed three distinct scrotal masses, all of equivalent size, consistent with testes (figures 3 and 4 ). The reported third testis was located in the left hemiscrotum. It was exquisitely tender and lay high in the midscrotum. All three masses had similar consistencies. At emergency scrotal exploration, two masses were identified in the

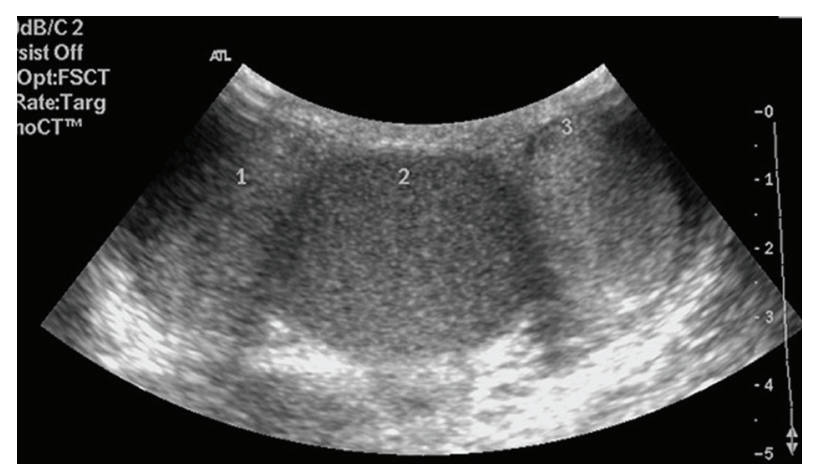

Figure 1 Preoperative scrotal ultrasound showing three structures of equivalent echogenicity.

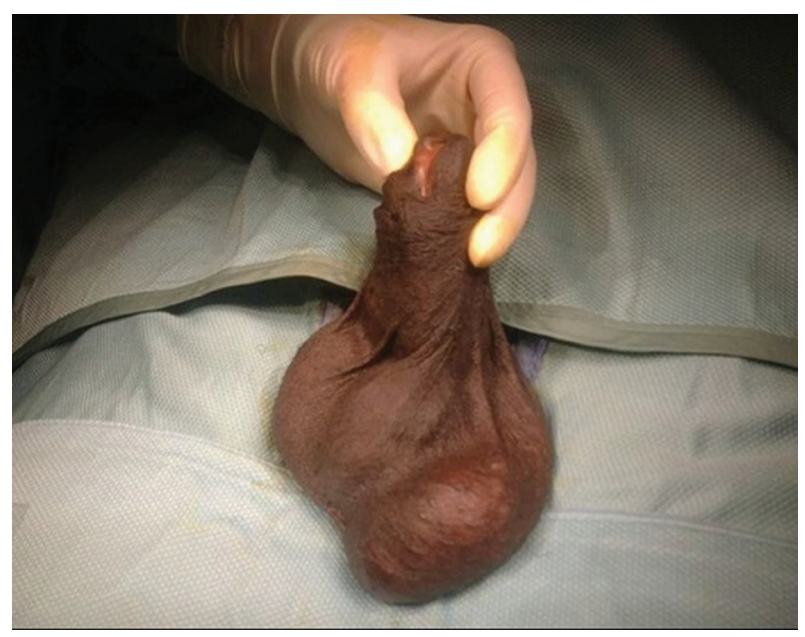

Figure 3 Three distinct scrotal masses. left hemiscrotum. There were no signs of testicular torsion. Incision of the third mass resulted in the expulsion of a copious quantity of thick brown material (figures 5 and 6). Pathology showed a saccular $6 \times 3 \times 2 \mathrm{~cm}$ epidermoid inclusion cyst, lined by keratinised squamous

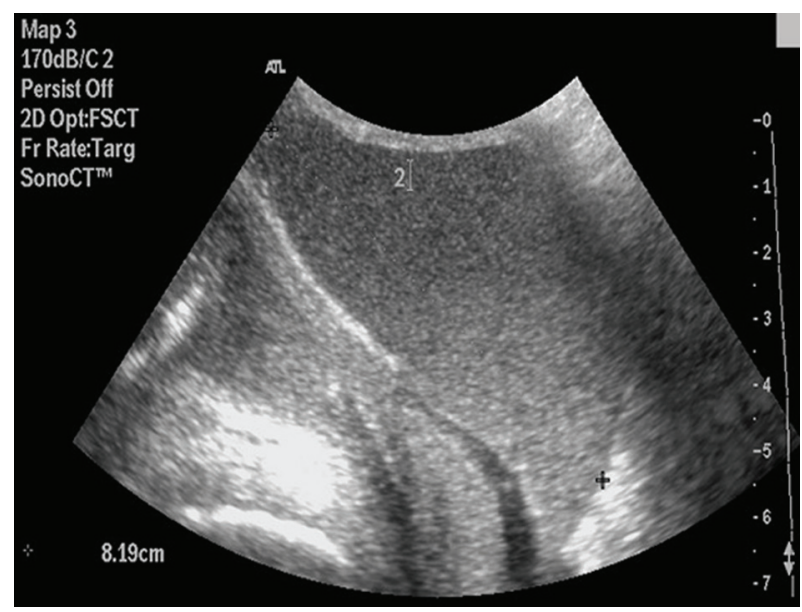

Figure 2 Ultrasonic view of the middle scrotal structure. Dimensions: $6.81 \times 3.46 \times 8.19 \mathrm{~cm}$. Tapered ends were seen. Poor colour flow Doppler was seen.

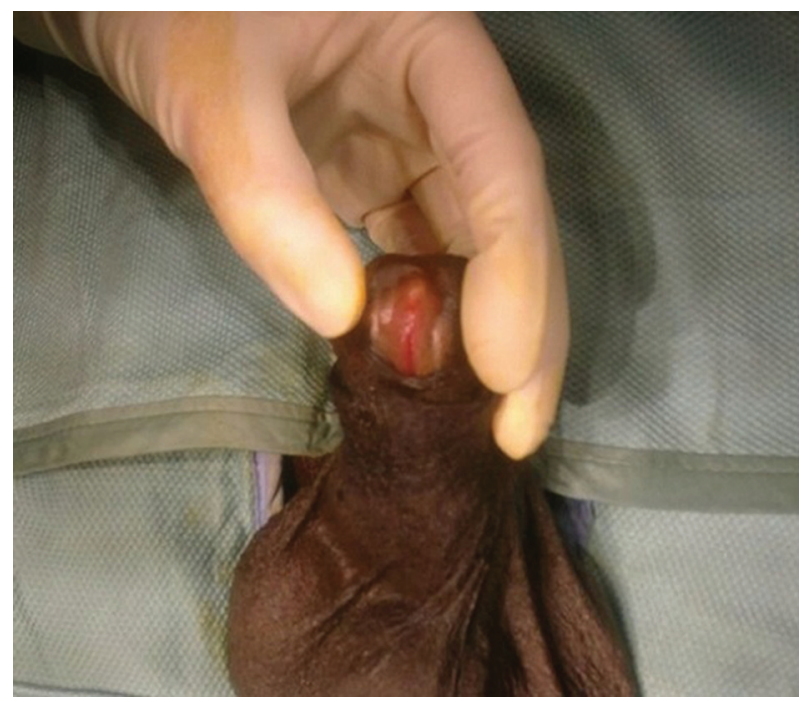

Figure 4 Anterior hypospadias. 


\section{BMJ Case Reports}

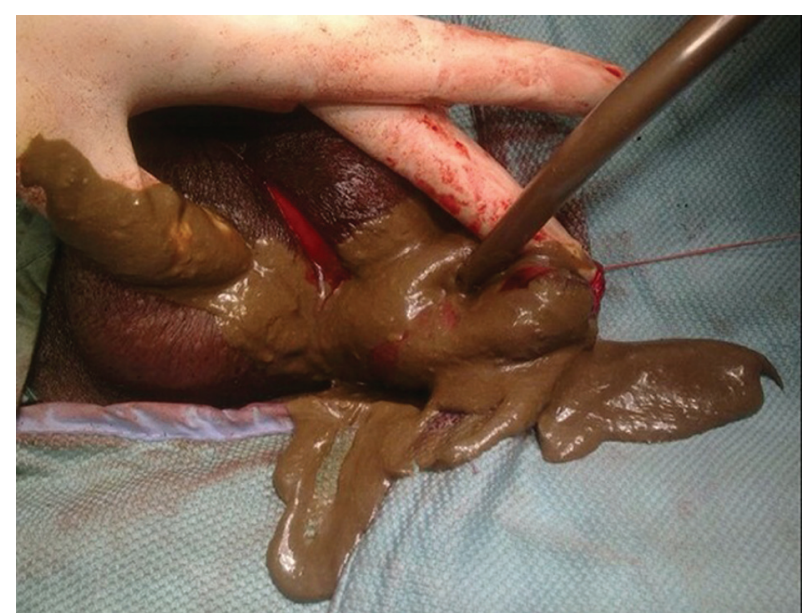

Figure 5 Incision of the middle scrotal structure.

epithelium and filled with sterile brown caseous material. The patient made an excellent postoperative recovery. He had no recurrence of scrotal pain at 6 months follow-up. Epidermoid inclusion cysts (EICs) occurred after implantation of epidermal tissue into the dermis or subcutaneous tissues. In the scrotum they are usually secondary to trauma or abnormal embryologic closure of the median raphe or urethral groove. ${ }^{1}$ They have a stratified squamous epithelial wall and often contain a laminated cheesy material. They appear solid on all imaging modalities and may have an onion-skin appearance. ${ }^{2}$ Characteristically EICs lack internal and capsular flow on colour Doppler ultrasound. They may mimic rare malignant tumours such as

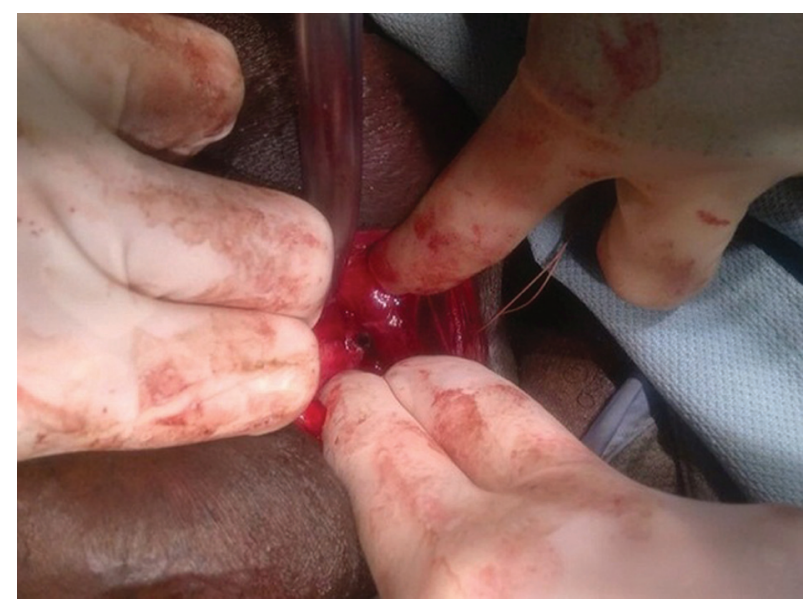

Figure 6 Following resection of the middle scrotal structure, the proximal aspect appeared to represent a blind-ending duct.

liposarcoma, fibrosarcoma or metastatic disease. Surgical excision is recommended.

Competing interests None.

Patient consent Obtained.

\section{REFERENCES}

1. Bergholz R, Wenke K. Polyorchidism: a meta-analysis. J Urol 2009;182:2422-7.

2. Lee HS, Joo KB, Song HT, et al. Relationship between sonographic and pathologic findings in epidermal inclusion cysts. J Clin Ultrasound 2001;29:374-83.

This pdf has been created automatically from the final edited text and images.

Copyright 2011 BMJ Publishing Group. All rights reserved. For permission to reuse any of this content visit http://group.bmj.com/group/rights-licensing/permissions.

BMJ Case Report Fellows may re-use this article for personal use and teaching without any further permission.

Please cite this article as follows (you will need to access the article online to obtain the date of publication).

Fanning DM, Mc Dermott T. An epidermoid cyst presenting as testicular torsion in a patient with tri-orchidism. BMJ Case Reports 2011; 10.1136/bcr.05.2011.4170, date of publication

Become a Fellow of BMJ Case Reports today and you can:

- Submit as many cases as you like

- Enjoy fast sympathetic peer review and rapid publication of accepted articles

- Access all the published articles

- Re-use any of the published material for personal use and teaching without further permission

For information on Institutional Fellowships contact consortiasales@bmjgroup.com

Visit casereports.bmj.com for more articles like this and to become a Fellow 